\title{
Fenomena Social Climber Ditinjau Dari Perspektif Etika Kristen
}

\author{
Simon $^{1)^{*}}$ \\ ${ }^{1}$ Sekolah Tinggi Teologi Salatiga \\ ${ }^{*}$ Email : petrus.simon26@yahoo.com
}

Diterima:12 Jul. 2019 / Direvisi:18 Okt. 2019 / Disetujui:11 Nov. 2019

\begin{abstract}
Abstrak
Social climber adalah orang yang memerankan dirinya sebagai kaum sosialita melalui aksesoris yang menempel di tubuhnya, tetapi keberadaan materinya tidak mendukung. Bagi mereka kepuasan hidup utamanya bertumpu pada hal material, akibatnya mereka pun kerap bersikap pamer dalam kehidupan sehari hari maupun di media sosial, dengan tujuan agar mendapatkan sanjungan. Corok kehidupan seperti ini harus diwaspadai karena berpotensi membuat pelakunya mengenyampingkan Tuhan. Adapun pendekatan metode yang digunakan dalam penulisan artikel ini adalah metode lingkaran pastoral dan studi literatur.

Pelaku social climber cenderung hanya berfokus pada kenikmatan duniai. Kehidupan yang hanya mementingkan unsur-unsur materialis bagian dari keinginan duniawi sebagaimana Alkitab kemukakan. Apabila sudah menjadi pelaku social climber akan merusak jati pribadi yang bersangkutan karena ia tidak bisa menerima keadaan dirinya, akibatnya hal yang salah akan dilakukan guna tuntunan menjadi social climber. Dampak yang bisa mengakibatkan pelakunya korupsi, menghalalkan segala cara untuk mendapatkan sesuatu, dan tentunya ini bertentangan dari perspektif etika Kristen yang mengajaran untuk hidup jujur dan bersyukur akan apa yang dimiliki.

Kata-kata kunci: Fenomena, Social, climber, Iman, Kristen, Materi.
\end{abstract}

\section{Abstract}

Social climber is a person who plays himself as a socialite through accessories attached to his body, but the existence of the material does not support. For them the main life satisfaction is based on material things, as a 
result they are often showing off in their daily lives and on social media, with the aim of getting flattery. This type of life must be watched out because it has the potential to make the culprit put aside God. The method approach used in writing this article is the pastoral circle method and literature study.

Social climber tends to only focus on worldly pleasures. A life that is only concerned with the materialist elements is part of worldly desires as the Bible says. If you have become a social climber, it will damage the personal identity of the person concerned because he cannot accept his condition, as a result the wrong thing will be done to guide you into a social climber. The impact that can lead to the perpetrators of corruption, justifies any means to get something, and of course this is contrary from the perspective of Christian ethics that teaches to live honestly and be grateful for what is owned.

Key words: Phenomenon, Social climber, Faith, Christianity, Material

\section{Pendahuluan}

Perkembangan zaman yang semakin moderen membuat arus globalisasi menjadi sangat cepat. Begitu pula dengan gaya hidup masyarakat yang juga mengikuti arus globalisasi tersebut. Akibatnya masyarakat menjadi semakin cenderung bergaya materialis yang cenderung mendominasi gaya hidup pada masa kini. Kehidupan yang hanya mementingkan hal-hal jasmani diprioritaskan tanpa lagi memperdulikan sisi kebutuhan spiritualitasnya. Dengan berlombalombanya orang di masa kini menampilkan kehidupan yang berbalut kemewahan dan menonjolkan hal material di publik, membuat sebagian orang untuk melakukan apa saja walau secara kematangan ekonomi mereka tidak mampu. Tetapi demi terlihat di publik, maka dicitrakanlah dirinya sekaya dan semewah mungkin. Orang yang ekonominya pas-pasan namun menonjolkan diri di publik dengan berbalutkan kemewahan serta bersikap pamer terhadap yang ia miliki disebut "social climber".

Fenomena social climber telah menjalar ke semua masyarakat tanpa memandang ras dan keyakinan, karena corak kehidupan yang ditampilkan oleh para pelaku social climber adalah kehidupan yang hanya berpusatkan kenikmatan jasmani sebagai keutamaan. Isu ini menjadi penting dibahas karena tanpa disadari social climber telah mewabah ke sebagian orang percaya karena telah dijangkit dan menjadi pelaku dari social climber itu sendiri. Dengan menguraikan topik ini, penulis bertujuan menyampaikan bahwa fenomena social climber ini perlu diperhatian dan diwaspadai oleh setiap orang percaya agar jangan sampai terjebak bahkan menjadi pelakunya, karena berpotensi menggeser 
Tuhan sebagai sentralitas dalam beriman, tergantikan dengan unsur-unsur materialis sebagai keutamaan apalagi bila dicapai dengan cara-cara yang salah sebagaimana para pelaku social climber. Untuk memberikan gambaran secara komperensif akan tulisan ini, maka penulis akan menjelaskan rumusan permasalahan pembahasan ini apakah social climber itu? Bagaimana ciri-ciri social climber? Di mana kita bisa lihat dan amati pelaku social climber? Apa dampak yang ditimbulkan dari social climber, serta bagaimana pandangan etika Kristen akan topik ini? Dengan menguraikan topik ini, diharapkan kita tidak ikut terbawa arus.

\section{Metode Penelitian}

Menurut Dedy Mulyana, metode adalah proses, prinsip dan prosedur yang digunakan untuk suatu pendekatan dalam mengkaji topik penelitian hingga mencari jawaban. ${ }^{1}$ Pembahasan pada artikel ini berkaitan menyoroti fenomena yang terjadi di sekitar, dan itu dapat dikatakan berkaitan bagian teologi kantekstual. Oleh karena itu, metode dalam penulisan artikel ini yang digunakan adalah metode lingkaran pastoral sebagaimana yang dikemukakan oleh E. Gerrit Singgih dalam buku "Vivat Crescat Floreat: Belajar \& Bertumbuh Bersama, Refleksi atas Setengah Abad Persetia. Adapun maksud dari metode lingkaran pastoral adalah menganalisis kuasa-kuasa struktural, dan membahas nilai-nilai yang menjadi dasar tindakan atau aksi. ${ }^{2}$ Di samping itu penelitian ini juga menggunakan pendekatan secara literatur. Adapun pendekatan literatur yang dimaksud adalah peneliti akan mengumpulkan data dari buku, jurnal dan media on-line yang berkaitan topik pada artikel ini. Kemudian peneliti akan merangkum dan mengambil kesimpulan dari yang diuraikan.

\section{Pembahasan}

\section{Social Climber}

Apakah yang dimaksud dengan social climber? Menurut Zakiah Darajat social climber adalah perilaku yang 'abnormal' karena individu terjebak dalam ekspetasinya sendiri sehingga ketika ekspetasi itu tidak sesuai dengan realita yang ada ia akan berusaha melakukan berbagai macam cara untuk meningkatkan status sosialnya. ${ }^{3}$ Pendapat senada dikemukakan oleh Adyindia social climber

${ }^{1}$ Dedy Mulyana, Metode Penelitian (Bandung: Rosdakarya, 2002), 120.

${ }^{2}$ E. Gerrit Singgih, Vivat Crescat Floreat: Belajar \& Bertumbuh Bersama, Refleksi atas Setengah Abad Persetia (Jakarta: BPK Gunung Mulia, 2014), 97.

${ }^{3}$ Zakiah Darajat, Kesehatan Mental (Jakarta: Gunung Agung, 1983),10. 
adalah seseorang yang berusaha untuk masuk pada kelas sosial tertentu (lebih tinggi) hanya untuk mendapat pengakuan akan status sosialnya yang tinggi. Akan tetapi hal ini sering menimbulkan suatu persepsi negatif, karena sebenarnya para social climber ini bukanlah kaum sosialita yang memang memiliki kedudukan dan materi yang berlimpah. ${ }^{4}$ Sedangkan psikolog Dinuriza Lauzi berkata social climber adalah "orang-orang yang tidak peduli dengan yang namanya proses untuk naik ke status sosial yang lebih tinggi. Image yang paling menonjol bagi pelaku social climber adalah gaya hidup di mana pengeluaran lebih besar dibanding pemasukan". 5

Biasanya orang yang mengidap perilaku social climber gaya hidupnya cenderung kelihatan bermewah-mewah. Para pelaku social climber pada umumnya mudah didekteksi dari gerak yang mereka perlihatkan. Para social climber ini cenderung suka memerkan hal material apa saja yang mereka miliki baik dalam kehidupan nyata maupun di kehidupan maya. Di kehidupan nyata misalnya, apabila ada perkumpulan seperti 'arisan', maka orang-orang yang berlabel social climber akan dengan sesumbar memamerkan apa yang mereka miliki seperti tas, alat elektronik yang bermerek dan lainnya. Dalam kehidupan maya, ia akan selalu cenderung memamerkan barang-barang yang ia pakai seolah ingain memperlihatkan bahwa ia seorang kaum sosialita. Penulis merangkum arti social climber dalam artikel ini adalah "orang yang berprilaku 'abnormal' karena ia berusaha menaikkan taraf hidupnya untuk masuk sebagai kaum sosialita (orang berada) dengan cara memamerkan barang-barang yang ia pakai, padahal sebenarnya tingkat kemapanan ekonomi tidak ditunjang dengan realita hidupnya. Tingginya ekspektasi diri untuk mengimetskan sebagai kaum sosialita melalui aksesoris yang dipakai menyebabkan pengeluaran lebih besar dibanding pemasukan karena kepuasan utama bagi pelaku social climber agar ia dipuji oleh karena aksesoris yang menempel dalam tubuhnya”.

\section{Kriteria Para Pelaku Social Climber}

Fenomena social climber sebenarnya bukan hal baru di dalam masyarakat. Sejak dulu, sudah ada orang-orang yang mendefinisikan diri mereka sebagai social climber, hanya saja namanya tidak sekeren sekarang ini. Ciri khusus social climber ini adalah fasilitas berbanding lurus dengan kepercayaan diri. Jika mereka mempunyai fasilitas atau barang bermerek, rasa percaya diri akan tinggi tapi jika mempunyai barang-barang unbranded, rasa minder pun muncul.

\footnotetext{
4 "fenomena-social-climber", https://www.kompasiana.com/anindyaliani

${ }^{5}$ Waspada-bahaya-social-climber", https://batam.tribunnews.com
} 
Social climber sangat mudah diidentifikasi dalam sebuah kelompok. Mereka cenderung paling attention seeker atau pencari perhatian, karena itu kepuasan mereka sebagai bagain dari kebutuhan. Yang mencolok dari social climber tentu saja lifestyle. Semua orang ingin statusnya naik setiap waktu tetapi para social climber tidak berusaha meraihnya dengan prestasi dirinya, tapi dengan simbol aksesoris yang yang menempel pada dirinya. Berikut ini ciricirinya pelaku social climber, dari buku dan artikel yang penulis rangkum:

1. Life style yang glamor

2. Menghalalkan segala cara untuk mendapatkan sesuatu

3. Kemewahan dan popularitas merupakan suatu kebutuhan

4. Tidak mengerti/menghargai proses

5. Kurang bersyukur

6. Cara berkomunikasi yang menjilat dan mulai memanfaatkan teman. ${ }^{6}$

7. Para social climber gila barang branded, seluruh tubuhnya yang menempel haruslah barang yang mempunyai brand.

8. Para social climber gila selfi dia akan sangat eksis memposting seluruh kegiatannya di media sosial.

9. Pelaku social climber selalu bertingkah bak kalangan elite selalu memaksakan tingkahnya kelihatan elegan di depan teman temanya.

10. Para social climber mempunyai teman yang sama visinya sehingga dia tidak mau berteman dari kalangan yang bukan kelompoknya.

11. Pelaku social climber menutup informasi tentang keluarganya

12. Social climber sangat terobsesi dengan pujian dan kekaguman dari orang lain. $^{7}$

\section{Orang-Orang yang Cenderung Berpredikat Social Climber}

Para Mahasiswa

Para pelaku social climber ini mayoritas mahasiswa. Hal ini dapat dilihat dari mayoritas mahasiswa yang cendrung mengikuti trend mode yang sedang buming saat ini serta dari gaya hidup yang glamor. ${ }^{8}$ Yang mencolok dari social climber tentu saja lifestyle. Mengapa, karena para pelaku social climber secara umum sudah di cap sebagai pribadi yang menampilkan kehidupan bermewahmewah namun ekonomi tidak mendukung. Biasanya pelaku dari social climber

${ }^{6}$ Molly Jong-Fast, The Social Climber's Handbook (New York: Villard Books, 2011), 34.

${ }^{7} \mathrm{http}: / /$ supraptiprapti.gurusiana.id/article/social-climber-2592560 (Diakses hari Sabtu, 6 Juli 2019, pukul 17:49.

${ }^{8}$ Ketrin \& Naan, Jurnal Syifa Al-Qulub, Vol. 3, No. 2, 2019, 132. 
ini cenderung mengarah kepada para wanita khususnya mahasiswi, merekalah yang kerap sering menunjukkan gaya hidup yang mengarah pada social climber. Mereka terjebak pada hal ini karena terkadang situasi menekan mereka sehingga mau tidak mau mereka dipaksa masuk di dalamnya. Pendapat senada dikemukan oleh Nurudin yang mengatakan, "Sangat ironis sekali di lingkungan mahasiswa banyak yang menjadi social climber dengan gaya hidup sok kaya ternyata latar belakang miskin, tentu fenomena ini membuat terkejut banyak mahasiswa yang kesehariannya terlihat bergaya moderen setiap penampilannya, akan tetapi pada saat seleksi beasiswa mahasiswa tersebut ternyata dari latar belakang keluarga miskin."9

Selain di kalangan mahasiswa, penyandang predikat social climber adalah para remaja, baik di tingkat Sekolah Menengah Pertama (SMP) maupun Sekolah Menengah Umum (SMU). Kondisi saat ini memerlihatkan bahwa banyak remaja yang membawa alat elektronik, meskipun sebenarnya belum membutuhkan atau belum mampu untuk membeli gadget-gadget mahal. Jika mereka tidak memiliki alat-alat elektronik tersebut, umumnya mereka merasa galau dan ingin cepat memperolehnya, karena akan dianggap tidak keren, cool dan menarik perhatian lingkungan sekitarnya." 10

\section{Di kalangan Pendeta dan Jemaat}

Apakah social climber ada di kalangan umat Tuhan dan rohaniawan? Tentunya ada, jika dilihat dari ciri-ciri social climber. Sebagai contoh dari kalangan rohaniawan, penulis melihat adanya pendeta, penggembalaannya masih tahap merintis, rumah masih sebatas mengontrak, namun sudah kredit modil. Ada lagi pendeta ia selalu memfokuskan agar ia mengganti mobilnya. Hal-hal yang penulis sebutkan sebenarnya jika ditinjau dari kemapanan ekonomi belum tepat berada pada hal itu, karena rumah masih kontrakan serta mobil belum menjadi kebutuhan utama bagi dirinya maupun dalam pelayanan yang dirintis. Dampaknya, mereka selalu menjadi pendeta yang 'meminta-minta pelayanan' dengan tujuan agar biaya kredit mobil selalu tercukupi. Penulis mengemukakan ini didasarkan pada fakta di lapangan yang ditemui dalam lingkup organisasi gereja di mana penulis juga merupakan sebagai gembala sidang.

\footnotetext{
${ }^{9}$ Nurudin \& Muyassarah, Menilik Perempuan Sebagai Social Climber Dalam Pandangan Ekonomi Islam. SAWWA, Volume 12, Nomor 2, April 2017, 228.

${ }^{10}$ Nurudin \& Muyassarah, Menilik Perempuan Sebagai Social Climber..., 229.
} 
Di lingkup jemaat bisa dilihat adanya anggota gereja yang kerap menampilkan hidup bermewah-mewah, akan tetapi realita ekonominya masih di bawah tingkat kemapanan. Kemewahan yang ditampilkan sering makan di restoran, terlalu memaksakan memiliki alat elekronik yang bermerek, hobi jalanjalan ke mall, sering nonton bioskop, suka berhutang dan sebagainya. Jika dilihat dari segi kemampanan ekonomi, apa yang dilakukan belum mampu untuk menjalani gaya hidup seperti itu. Ini bukanlah asumsi penulis, tetapi penilain ini berangkat dari pengamatan sebagai gembala sidang yang melihat dan bertemu bahwa adanya sebagian jemaat sebagai pelaku social climber.

\section{Di manakah Isu Social Climber Ini Terjadi}

Isu social climber ini dapat ditemukan khususnya di jejaring social. Ada beberapa petunjuk mengenai hal ini, pertama, isu social climber ini dapat ditelusuri dan dilihat di jejaring media sosial seperti Facebook, Instagram, Twiter. Media sosial sebagai tempat alternatif yang pertama untuk mendeteksi para pelaku sosial climber ini, karena di media social para pelaku social climber ini akan menunjukkan eksistensi. Biasanya, para pelaku social climber suka memamerkan segala sesuatu, padahal dia berasal dari golongan menengah ke bawah. ${ }^{11}$ Social climber pada umumnya cukup jelas untuk dikenali, karena tujuan utama mereka adalah mendapat perhatian publik dengan gaya yang berlebihan. Oleh sebab itu fenomena social climber ini dapat dilihat dan diamati keberadaannya di dunia maya. Menurut psikolog lulusan Universitas Indonesia, Ratih Zulhaqqi, para social climber umumnya membutuhkan perhatian akibat sebagian jiwanya kosong dan butuh 'pemenuhan', dan salah satu cara pemenuhannya adalah dengan mencari perhatian dalam bentuk memamerkan barang-barang mahal. ${ }^{12}$

Kedua adalah di kota besar yang memiliki tingkat mobilitas hidup tinggi. Di Indonesia, khususnya seperti Jakarta, Surabaya, Bandung, Medan dan kotakota besar lainnya, tingkat mobilitas hidup penduduknya amatlah tinggi. Hal ini terjadi karena padatnya jumlah penduduk, ragamnya profesi manusianya, terlebih pesatnya hiburan dan ditopang dengan padatnya kegiatan di kota ini membuat para penduduknya mengalami berbagai hal. Dengan tingginya mobilitas penduduk di kota ini, maka mudah untuk mengamati setiap orang yang berpredikat sebagai social climber. Tingginya mobilitas hidup di kota-kota

\footnotetext{
${ }^{11} \mathrm{https}$ //Www.finansialku.com/social-climber/

12 "saran-psikolog-saat-hadapi-perilaku-social-climber-di-medsos" dalam https://health.detik.com/berita-detikhealth/ (Diakses 16 September 2019, pukul 9.52 WIB).
} 
tersebut karena didukung kemajuan banyaknya pabrik industri, berbagai perguruan tinggi, usaha kerajinan tangan, pusat hiburan seperti mall, bioskop, café, dan lainnya. Belum lagi berbagai suku di Indonesia yang merantau untuk mencari nafkah. Hal-hal itu yang mendorong semakin tingginya mobilitas hidup di kota-kota yang disebutkan di atas. Kehidupan mobilitas yang tinggi turut juga memengaruhi corak kehidupan yang ditampilkan yang mengarah pada social climber.

Ketiga adalah di lingkungan sekitar, bahkan di gereja. Orang yang menonjolkan hal material dan bersikap pamer akan apa yang dimiliki adalah selalu identik dengan perilaku sebagai pelaku social climber. Ciri-ciri social climber ini tidak hanya terdapat di kota-kota besar saja, tetapi keberadaan oknumnya juga dapat dideteksi di mana mereka tinggal maupun dalam di lingkup gereja. Sebagai contoh di lingkup gereja, pastilah ada jemaat yang sangat berlebihan dengan penampilannya ketika beribadah di gereja. Penampilan yang berlebihan itu diantaranya memakai perhiasan emas yang berlebihan pada saat beribadah. Berdasarkan wawancara penulis dengan responden yang bernama Rismawati Simarmata ia berkata: "Sebagian orang Batak kalau ibadah ke gereja pada hari minggu, mereka kerap pamer perhiasan emas yang dipakainya, baik itu cincin, kalung dan gelang besar yang melingkar di jari dan tangannya."13

Memakai barang-barang bermerek maupun emas sampai menjadi menjadi perhatian bagi sebagian jemaat, tentunya ini bukan bagian dari kebudayaan tetapi itu sudah pada kategori ke pameran yang ditonjolkan. Walau bukan hanya suku Batak saja sebagai pelaku hal ini, tetapi penulis mengambil contoh dari suku Batak didasarkan karena penulis pun berada pada suku yang sama dan memahami karakteristiknya. Bila sudah menjadi perhatian di antara jemaat yang lain, bukankah itu mengarah pada pola perilaku social climber. Tentunya Ini merupakan keprihatinan karena sebagian orang-orang Kristen malah menjadikan ibadah sebagai ajang pamer akan apa yang dimiliki melalui aksesoris yang dipakainya.

\section{Permasalahan yang Ditimbulkan Para Pelaku Social Climber}

Dampak yang ditimbulkann social climber ini adalah: pertama, membuat para pelakunya korupsi. Korupsi bisa terjadi karena adanya keinginan untuk

${ }^{13}$ Wawancara penulis dengan ibu Rismawati Simarmata pada hari Senin, 15 Juni 2019 pukul 09. 34 WIB. Responden aktif dalam mengikuti perkumpulan orang Batak dan paham betul karakteristik orang-orang Batak. 
hidup mewah, tetapi pendapatannya tidak menunjang keinginan tersebut. Psikolog Roslina Verauli mengungkapkan pelaku social climber ingin mendapatkan kehidupan layaknya orang kaya, namun pada kenyataannya tidak demikian, karena secara finansial tidak sanggup. ${ }^{14}$ Sebagai contoh, pegawai negeri golongan I menginginkan hidup dengan rumah megah, mobil mewah, barang-barang keseharian yang berharga puluhan sampai ratusan juta, tentu gaji menjadi PNS tidak bisa mencukupi, dan jalan pintasnya adalah korupsi. Akibatnya para social climber yang mau terlihat kaya namun tidak melalui proses yang benar, bahkan di antara mereka juga sampai melakukan penipuan untuk hidup mewah. ${ }^{15}$ Oleh sebab itu sikap "social climber" merupakan salah satu dari akar korupsi yang sekarang mendera bangsa ini. Mereka bahkan hanya melihat bahwa prestasinya adalah segala hal yang dia miliki sepanjang hidupnya, seperti barang mewah, kemudahan akses, dan perlakuan khusus tanpa memperdulikan mengenai pencapaian dalam karir, kedewasaan, dan pengetahuan." 16

Sebagai contoh adalah Gayus Tambunan, yang hanya seorang pegawai pajak dari golongan 3A namun hartanya diperkirakan ratusan miliar lebih. Di tahun 2010-2011 media pertelevisian dan dunia maya dibuat heboh oleh kasus korupsi yang dilakukan oleh Gayus. Publik Indonesia menyoroti kasus korupsi yang dilakukan oleh Gayus, karena ia melakukan penyalahgunaan wewenang dengan menerima suap dari wajib pajak dan pidana. Ia dinyatakan terbukti bersalah menerima suap senilai Rp. 925 juta dari Roberto Santonius, konsultan PT Metropolitan Retailmart, terkait kepengurusan keberatan pajak perusahaan tersebut. Ia juga lalai menangani keberatan pajak PT Surya Alam Tunggal (SAT), terlibat dalam kasus penggelapan pajak PT Megah Citra Raya, serta menerima gratifikasi saat menjabat petugas penelaah keberatan pajak di Ditjen pajak. $^{17}$

Salah satu label dari pelaku social climber adalah tamak. Mereka yang labelnya menjadi seorang social climber tentunya tidak akan mementingkan

14 "suka-pamer-seperti-social-climber-ini-dampaknya-bagi-kesehatan-jiwa", https://health.detik.com/berita-detikhealth/ (Diakses 14 September 2019, pukul. 20.41).

15 "mengenal-social-climber-orang-miskin-yang-ingin-kelihatan-kaya", https://www.inovasee.com/ (Diakses hari Rabu 31Mei 2017).

16 "social-climber-penyakit-sosiologia-dan-psikologis", https://www.kompasiana.com/retina/

17 "rentetan-kasus - korupsi-yang-menjerat-pegawai-pajak", https://www.cnnindonesia.com/nasional/(diakses hari Sabtu 14 September 2019, pukul 11. 48 WIB. 
ketulusan dan kejujuran dalam mencapai sesuatu, karena bagi mereka prioritasnya untuk bisa sejajar dan dapat diterima di komunitas yang lebih elit serta akan semewah mungkin menampilkan citra dirinya walau tidak ditopang dengan materi dan penghasilan yang mumpuni.

Dampak kedua yang bisa ditimbulkan akibat terjangkiti predikat social climber adalah menderita sakit jiwa; namun bukan karena gila atau tidak waras, melainkan karena ingin memerlihatkan diri tidak sesuai dengan apa yang sedang dialaminya saat ini. Ingin terlihat kaya padahal sesungguhnya miskin dan tidak memiliki kemampuan sama sekali secara ekonomi. Jika ditinjau dari kesehatan mental maka para social climber ini bisa disebut juga sebagai orang-orang yang memiliki gangguan mental. Zakiah Darajat mengatakan, "Orang yang sakit jiwanya mereka cenderung cemas, tidak bahagia, gampang marah, sombong, serta suka berbohong. Hal ini terjadi pula pada diri social climber karena kebanyakan mereka menutupi keadaan mereka dengan memperlihatkan apa yang mereka punya. Bahkan terkadang mereka rela berbohong dan mengakungaku barang orang lain sebagai miliknya jika itu bisa membuat status sosialnya lebih tinggi." 18

Bersikap pamer dan memerlihatkan diri seakan kaya dan mumpuni secara ekonomi dengan berusaha menutupi realita hidupnya dengan balutan aksesoris yang menempel dalam dirinya, itulah yang disebut sebagai penyakit jiwa. Sigmund Freud mengemukakan, sebagaimana dikutip oleh Bhasin, bahwa social climber sangat memengaruhi aspek biologis dan aspek psikologis setiap perempuan dan berpengaruh pada kemampuan dan peran sosialnya. Doktrin Freudian ini berkembang luas, yang kemudian dianut oleh banyak kalangan, dan menjadi pedoman dan acuan bagi para pendidik, pekerja sosial maupun politisi. ${ }^{19}$ Oleh karena itu social climber adalah salah satu penyakit sosiologis dan psikologis yang dapat meruntuhkan juga harkat serta martabat sebuah bangsa. ${ }^{20}$

Ketiga, secara umum social climber menggunakan segala cara untuk menggapai materi. Mulai dari meminta dan mengancam orang tua, memanfaatkan teman atau pacar bahkan melakukan tindakan kriminal. ${ }^{21}$ Dampak yang ditimbulkan dari social climber ini adalah pelakunya akan

${ }^{18}$ Darajat, Kesehatan Mental, 5.

${ }^{19}$ Kamla Bhasin, Menggugat Patriarki-Pengantar tentang Persoalan Dominasi terhadap Kaum Perempuan (Yogyakarta: Yayasan Bentang Budaya, 1996), 30.

20 "social-climber-penyakit-jiwa-meruntuhkan-bangsa", https://hanyalewat.com/

21 “social-climber-penyakit-jiwa-meruntuhkan-bangsa", https://hanyalewat.com/ 
menghalalkan segala cara untuk mendapatkan keinginan hati. Mengapa, karena kecenderungan kehidupan mereka terlalu berorientasi pada kebutuhan biologis. Yusuf L.N. mengemukakan, "Kehidupan yang terlalu berorientasi kepada kemajuan dalam bidang material (pemenuhan kebutuhan biologis) dan melupakan dimensi rohaniah, sangat berpengaruh buruk kepada pola perilaku manusia sendiri. Kondisi ini ternyata sangat kondusif bagi berkembangnya masalah-masalah pribadi dan sosial yang terekspresikan dalam suasana psikologis yang kurang nyaman, seperti perasaan cemas, stress, dan perasaan terasing, serta terjadinya penyimpangan moral atau sistem nilai." ${ }^{22}$

Dari ungkapan di atas dapat dimengerti bahwa menjadi seorang social climber sangatlah berbahaya, sebab kehidupannya akan berdampak yang negatif. Jika dikaitkan dengan psikologi teori psikoanalisa Sigmund Freud, maka yang terjadi dalam diri para social climber ini adalah kurangnya kontrol diri. Hal ini terjadi karena kurangnya kontrol (superego) pada diri individu sehingga individu cenderung dikendalikan oleh keinginan sehingga ego dalam individu melaksanakan apa yang mendominasi pada diri seseorang tersebut. ${ }^{23}$ Orangorang yang sudah terjangkit social climber hidupnya akan berpusat untuk bisa mendapatkan pujian dan pengakuan bahwa ia adalah seorang elit, dan itu merupakan kepuasan baginya.

Keempat, apabila orang kaya mencitrakan dirinya hidup mewah dan glamor merupakan hal yang lumrah, karena kemewahan yang ia perlihatkan adalah hasil dari proses kerja keras dan ketekunan yang ia lakukan. Ia menerima semua itu sebagai reward (hadiah) dari proses kerja keras dan ketekunanya. Meskipun demikian, prioritas dirinya tidaklah ditempatkan pada sisi itu. Hal ini berbeda dengan mereka yang berkategori manusia social climber, karena hidupnya hanya terfokus pada mengejar dan mencitrakan dirinya sebagai orng kaya dan glamor dengan memerlihatkan gaya hidupnya; padahal gaya hidupnya tidak ditopang oleh kematangan secara materi dan ia cenderung tertutup akan kehidupannya yang sebenarnya.

Seorang social climber melihat bahwa letak prestasinya adalah pada halhal yang dia miliki sepanjang kehidupannya. Barang mewah, kemudahan akses dan perlakuan khusus adalah ukuran prestasi/pencapaian mereka dan bahkan sering kali mereka tidak memedulikan mengenai pencapaian dalam karier, kedewasaan, dan pengetahuan. Hal ini terjadi karena mereka melihat bahwa

\footnotetext{
${ }^{22}$ Syamsu dan Yusuf L.N., Kesehatan Mental-Perspektif Psikologis \& Agama (Bandung: PT Remaja Rosdakarya, 2018), 103-104.

${ }^{23}$ K. Bertens, Psikoanalisa Sigmund Freud (Jakarta: Gramedia Pustaka Utama, 2006), 33.
} 
kelompok sosial elit yang mereka sasar juga memiliki hal-hal tersebut. Para pelaku social climber tidak suka dan tidak mau menjalani proses untuk menjadi sukses, mereka hanya menginginkan bagaimana caranya terlihat hidup mewah dan bergelimang harta tanpa menjalani proses. Oleh karena itu para social climber sangat berambisi untuk mencitrakan hidup yang mewah tanpa mau menjalani proses yang panjang, apalagi menjalaninya. Oleh karena itu, prinsip hidup yang dianut oleh pelaku social climber sangat 'tidak sehat' secara mental, karena tidak menampilkan kewajaran hidup serta tidak berdampak positif bagi orang lain. Karena orang yang sehat mental akan menampilkan perilaku atau respon-respon terhadap situasi dalam rangka memenuhi kebutuhannya, memberikan dampak yang positif bagi dirinya sendiri dan orang lain. Dia mempunyai prinsip bahwa tidaklah baik jika mengorbankan hak orang lain demi kepentingan dirinya sendiri, atau mencari keuntungan diri sendiri di atas kerugian orang lain. ${ }^{24}$

Bagi para social climber, kepuasan utama hidup mereka terletak pada pengakuan bahwa mereka telah hidup setara dengan kaum elite yang sudah mapan secara ekonomi. Karena itu, untuk mendapatkan pengakuan kesetaraan dengan komunitas elit yang kaya, maka para social climber akan sesering mungkin bersikap pamer dengan menampilkan apa yang mereka pakai dan miliki.

Kelima, umumnya status ekonomi para pelaku social climber tidak begitu bagus, namun mereka memaksakan untuk mendapatkan segala fasilitas mewah supaya mendapat pengakuan seperti yang mereka harapkan. Perilaku social climber melekat erat dalam diri seseorang yang tidak memiliki kesadaran diri dalam hidupnya, yaitu tidak mempunyai budaya malu dalam dirinya karena tidak melihat realita keadaannya. Akibat kurangnya kesadaran diri ini, maka pelaku social climber akan melakukan tindakan buruk atau tidak terpuji guna pemenuhan kebutuhan terhadap barang-barang mewah untuk dipublikasikan kepada khalayak umum. Soemarno Soedarsono menjelaskan bahwa kesadaran diri merupakan perwujudan jati diri pribadi, dan seseorang dapat disebut sebagai pribadi yang berjati diri tatkala dalam pribadi orang yang bersangkutan tercermin penampilan, rasa cipta dan karsa, sistem nilai (value system), cara pandang (attitude) dan perilaku (behavior) yang dimiliki. ${ }^{25}$

${ }^{24}$ Yusuf L.N., Kesehatan Mental Perspektf Psikologis \& Agama,....30.

${ }^{25}$ Soemarno Soedarsono, Penyemaian Jati Diri, (Jakarta: Elek Media Komputindo, 2000), 96. 
Para pelaku social climber dilabeli kurang memiliki kesadaran diri, karena perilaku hidup yang ditampilkan cenderung tidak sesuai dengan realita keadaan hidup mereka. Cara yang digunakan oleh para social climber ini untuk mendapatkan berbagai fasilitas setara kelas sosial yang lebih tinggi dapat dikatakan tidak jauh dari kata buruk, karena kurangnya materi penunjang untuk pemenuhan keinginannya tersebut, ada yang meminjam uang, ada pula yang menjual barang pemberian orang tua, mendekatkan diri pada kelompok sosial yang lebih tinggi hanya untuk mendapat pengakuan dari kelompok tersebut. Cara yang paling biasa dilakukan oleh para kaum social climber adalah mencari teman kencan yang memiliki segudang fasilitas mewah untuk dimanfaatkan, sehingga mereka ikut merasakan fasilitas kelas tinggi tersebut kemudian menceritakan kepada rekan-rekannya agar mendapat pengakuan atas pencapaian tersebut. Dan tentunya hal ini bukanlah pencapaian dalam hal yang positif. ${ }^{26}$

\section{Dasar Etika Moral dan Hukum dari Pembahasan topik ini}

Merebaknya isu social climber ini harus menjadi perhatian bagi setiap individu. Jika ditinjau dari sudut pandang etika, social climber ini tidak bisa dibenarkan karena melanggar norma-norma kewajaran. Perilaku Social climber tidak menampilkan kewajaran sebagaimana seharusnya hidup dan selalu bersikap hidup mewah, padahal realitanya pelaku social climber tidak mapan secara finansial.

Bila ditinjau dari sisi hukum, dengan merujuk pada aturan pemerintah yaitu Surat Edaran (SE) Menteri Pendayagunaan Negara dan Reformasi Birokrasi (Menpan-RB) Nomor 13 Tahun 2014 tentang: Gerakan Hidup Sederhana, diungkapkan tentang empat butir penting tentang perilaku hidup sederhana. Keempat butir tersebut adalah: pertama, membatasi jumlah undangan resepsi penyelenggaraan acara seperti pernikahan, syukuran, dan acara sejenis lainnya, maksimal 400 undangan dan membatasi jumlah peserta yang hadir tidak lebih dari 1.000 orang. Kedua, tidak memerlihatkan kemewahan atau sikap hidup yang berlebihan serta memerhatikan prinsipprinsip kepatutan dan kepantasan sebagai rasa empati kepada masyarakat. Ketiga, tidak memberikan karangan bunga kepada atasan atau sesama pejabat pemerintah. Keempat, membatasi publikasi advertorial yang menggunakan 
biaya tinggi. ${ }^{27}$ Butir nomor kedua dan dan keempat dapat dijadikan sebagai acuan hukum mengenai isu social climber.

\section{Sosial Climber Ditinjau dari Perspektif Etika Kristen}

Dalam uraian di atas dapat ditemukan sebuah kerangka berpikir bahwa perilaku social climber sebenarnya menunjuk pada perilaku hidup yang tidak berfokus kepada Allah, lebih condong pada kenikmatan jasmani dibandingkan hal rohani, dan menjadikan mamon bagai tuhan bagi pelakunya. Di bawah ini akan dibahas dan dianalisa perilaku social climber dari sudut pandang etika Kristen.

Pertama, sikap social climber membuat hidup tidak berfokus kepada Allah. Fenomena social climber di masa kini harus menjadi perhatian bagi orang percaya agar jangan sampai terjebak dan menjadi pelakunya. Bagaimana tanggapan Alkitab terhadap social climber ini? Apa yang menjadi solusi dan himbauan Alkitab agar tidak sampai menjadi pelaku social climber?

Bila dikaji dari sudut pandang firman Allah, tentunya social climber ini salah dan keliru. Dikatakan salah karena jika ditelisik sikap social climber memiliki motif utama ingin mencari dan mendapatkan pengakuan kesetaraan sosial dan layak berada pada posisi golongan yang eliet. Jika ini yang menjadi motif utama dari setiap pelaku social climber, maka dapat dikatakan bahwa hal itu merupakan penyimpangan dari kaca mata Alkitab, sebab si pelaku menjadikan keinginan duniawi sebagai pusat dari tujuan hidupnya. Hal ini bertentangan dengan firman Tuhan yang mengatakan, "Pikirkanlah perkara yang di atas, bukan yang di bumi. Sebab kamu telah dibeli dan hidupmu tersembunyi bersama dengan Kristus di dalam Allah.” (Kol. 3:2-3). Di Perjanjian Lama, ketika Allah memberikan Hukum Taurat kepada orang Israel, secara jelas dinyatakan agar tidak boleh ada allah lain yang menjadi fokus utama dalam hidup umat Tuhan (Kel. 20:3), dan yang dimaksud dengan allah lain, bila diterjemahkan di masa kini, dapat merujuk pada kenikmatan duniawi yang mengusai hati dan pikiran manusia. Selain itu pengaruh dari social climber dapat menumpulkan kesadaran seseorang tentang fokus utama hidup di dunia, yaitu menjalin relasi dengan Allah, sebagaimana yang dikemukakan oleh Scazzero "kesadaran akan diri sendiri dan relasi anda dengan Allah sangatlah terkait. Bahkan, tantangan untuk mengenyahkan manusia lama kita yang palsu

\footnotetext{
${ }^{27}$ Dikutip dari salinan surat edaran Menteri Pendayagunaan Aparatur Negara dan Reformasi Birokrasi Republik Indonesia, yang diterbitkan tanggal 4 November 2014, dalam website https://www.menpan.go.id/site/
} 
untuk bisa hidup secara autentik dalam manusia baru kita berada pada inti dari kerohanian yang sejati." 28

Social climber membuat para pelakunya bukan berfokus kepada Tuhan, tetapi berfokus kepada kenikmatan duniawi. Apabila kenikmatan jasmaniah dijadikan dasar kehidupan, betapa malangnya mereka yang hidup mendasarkan kemewahan di atas segalanya, karena dalam Alkitab ditegaskan, "Dan kalau kepada Kristus hanya untuk kehidupan di dunia ini saja, kitalah yang paling malang di antara semua manusia" (1 Kor. 15:19). Sikap yang Yesus inginkan dari manusia ialah tidak pamer diri. Yesus tidak ingin manusia bergantung pada kemewahan, dan Ia mencari orang yang memiliki sikap hati yang benar, motif yang tepat." 29

Kedua, sikap social climber lebih condong pada kenikmatan jasmani daripada rohani. Bagi pelaku social climber, kesukaan utama dalam diri hanya terletak pada kenikmataan dan kesenangan duniawi, seperti kehidupan yang berbalut kemewahan, pembanggaan diri akan aksesoris yang menempel dalam dirinya. Para pelaku social climber merasa bahwa yang dapat membuat hidup mereka bahagia dan berbangga apabila dapat menikmati kesenangan duniawi sebagai bentuk dari pemuasan jasmaniah. Makanya tidak heran jika prioritas social climber hanya satu yaitu, upload foto keren di media sosial, terutama Instagram. Tujuannya, agar orang lain memberikan 'like'kepadanya dan menuliskan comment tentang bertapa kerennya dia. Selain itu, dia akan lebih suka menghabiskan harinya untuk foto-foto sebagus mungkin dengan jalan-jalan ke tempat bagus atau makan di restoran yang bergaya." 30

Corak kehidupan seperti ini tidak akan berdampak pada kehidupan rohani, karena kepuasan jasmani sudah menjadi fokus utama. Alkitab menegaskan agar manusia tidak terlena dengan kenikmatan duniawi, karena itu bagian dari keinginan daging, "Janganlah kamu mengasihi dunia dan apa yang ada di dalamnya. Jikalau orang mengasihi dunia, maka kasih akan Bapa tidak ada di dalam orang itu. Sebab semua yang ada di dalam dunia, yaitu keinginan daging dan keinginan mata serta keangkuhan hidup, bukanlah berasal dari Bapa, melainkan dari dunia. Dan dunia ini sedang lenyap dengan keinginannya, tetapi

${ }^{28}$ Peter Scazzero, Emotionally Healtyy Spirituality. (Surabaya: Literatur Perkantas Jawa Timur, 2017), 79.

${ }^{29}$ Andrew Brake, Spiritual Formation. (Bandung: Yayasan Kalam Hidup, 2013), 115.

30 "awas-5-tanda-social-climber-yang-paling-mencolok", https://womantalk.com/friendship/articles/ 
orang yang melakukan kehendak Allah tetap hidup selama-lamanya." (1 Yoh. 2:17-17).

Dengan berfokus pada kemewahan serta bersikap pamer akan aksesoris yang dipakai oleh para pelaku social climber, akan menumbuhkan sifat malas dalam bekerja dan cenderung instan dalam meraih apa yang diharapkan. Allah menghendaki manusia menjadi umat-Nya yang memiliki kesadaran untuk rajin bekerja agar berkat-Nya dilimpahi. Scott mengungkapkan bahwa Kerja merupakan bagian yang tak dapat dipisahkan dari nilai kemanusiaan. Dengan demikian harus diakui bahwa kondisi menganggur (dan bukannya sibuk) merupakan pengingkaran dari salah satu unsur asasi dari kemanusiaan, sekaligus menentang kehendak Allah bagi kehidupan. Dengan demikian manusia yang tidak bekerja akan kehilangan sebagian dari kemajuannya sebagai manusia sejati." 31

Selain itu bahaya dari social climber dapat memengaruhi seseorang termasuk lingkungan di sekitarnya. Hal senada dikemukakan oleh Nurudin \& Muyassarah, yang mengatakan bahwa social climber akan memengaruhi seseorang untuk ikut berbuat apa yang dilihat dari penampilan temanya. Maraknya kaum sosialita sebagai komunitas juga memengaruhi kehidupan sosial masyarakat. ${ }^{32}$ Social climber, bila ditinjau dari Etika Kristen, membuat pelakunya meletakkan kemewahan duniawi yang bersifat kedagingan sebagai sentralitas hidup, menggeser posisi Tuhan. Hal ini salah dalam perspektif firman Tuhan, karena Alkitab menulis agar setiap orang percaya harus mendasarkan kehendak utamanya dalam pengenalan akan Tuhan, supaya beroleh kebangkitan dan persekutuan bersama dengan Kristus (Fil. 3:10-11).

Ketiga, sikap social climber adalah sikap yang menuhankan Mamon. Social climber sering sekali membuat para pelakunya menjadi orang yang tidak kreatif dalam pengembangan diri, akibatnya kegigihan untuk bekerja keras tidak tercipta. Padahal Tuhan selalu menghargai semua orang yang rajin dan mau bekerja keras dengan cara memberi upah yang pantas mereka terima. ${ }^{33}$ Pelaku social climber akan sebisa mungkin menampilkan diri untuk tampil mewah dan glamor dengan balutan material. Corak hidup seperti ini akan menjadikan mereka sebagai manusia yang "menuhankan mammon", tanpa peduli lagi

${ }^{31}$ John Stott, Isu-Isu Global Menentang Kepemimpinan Kristiani. (Jakarta: Yayasan Bina Kasih/OMF, 1996), 217-218.

32 Nurudin \& Muyassarah, Menilik Perempuan Sebagai Social Climber Dalam Pandangan Ekonomi Islam", 228.

${ }^{33}$ Benny Santoso, Bebas dari Kekurangan Uang. (Yogyakarta: ANDI, 2010), 105. 
pencipta mereka yang sebenarnya, dan kehidupan seperti ini sangat ditentang oleh firman Tuhan. Yesus berkata "Tak seorang pun dapat mengabdi dua tuan, karena jika demikian, ia akan membenci yang seorang dan mengasihi yang lain, atau ia akan setia kepada yang seorang dan tidak mengindahkan yang lain. Kamu tidak dapat mengabdi kepada Allah dan Mamon." (Mat. 6:24).

Yesus menyatakan hal karena Ia menghendaki agar manusia tidak beralih dari Dia dan terus menempatkan Dia sebagai prioritas utama kehidupan. Tasiran Alkitab MHC menguraikan ayat ini dengan memberikan penjelasan "peringatan yang baik agar kita tidak menjadikan hal-hal yang tampak, yang hanya sementara, sebagai hal yang kita anggap paling penting, dan agar kita tidak mengandalkannya untuk memberi kita kebahagian. ${ }^{34}$ Bagi para social climber, yang menempatkan uang sebagai tuhan, akan selalu memiliki perasaan berkekurangan, karena, uang, di samping dapat dianggap sebagai penyelesai masalah atau bisa membuat kehidupan menjadi lebih baik serta bisa meningkatkan status, ${ }^{35}$ namun uang juga dapat mengakibatkan manusia menjadi serakah karena jiwanya telah dikuasai secara penuh oleh uang (mammon).

\section{Solusi Agar Tidak Menjadi Pelaku Social Climber}

Hal pertama yang dapat menjadi solusi agar fenomena social climber ini tidak mengerogoti pikiran dan kehidupan orang percaya adalah hidup dengan rasa bersyukur. Rumah mewah bukan jaminan keluarga bahagia. Saling mengasihi, menghormati, dan memaafkan, itulah kunci keluarga bahagia. Gaji tinggi bukan jaminan kepuasan hidup. Bersyukur, berbagi, dan saling menyayangi, itulah kunci kepuasan hidup. Kaya raya bukan jaminan hidup terhormat. Tapi jujur, sopan, murah hati, dan menghargai sesama, itulah kunci hidup terhormat. Hidup berfoya-foya bukan jaminan banyak sahabat. Tapi setia kawan, bijaksana, mau menghargai, menerima teman apa adanya dan suka menolong, itulah kunci banyak sahabat. ${ }^{36}$

Hidup bersyukur dapat diartikan menerima keadaan hidup yang dimiliki. Kehidupan bersyukur mencegah tidak mengikuti arus hidup yang serba materialistis, sehingga orang percaya memiliki prinsip yang teguh dan punya identitas tanpa dirubah oleh apapun. Oleh sebab itu dengan menganut hidup

${ }^{34}$ Tafsiran Alkitab MHC, versi Eloktronik.

${ }^{35}$ Benny Santoso, Bebas dari Kekurangan Uang, 33-34.

${ }^{36}$ Widhi Arief Nugroho, "Peranan Pendidikan Keluarga Tentang kekudusan Hidup Menurut Roma 12:1-2, Fidei: Jurnal Teologi Sistematika dan Praktika, Vol. 1, No. 2, 2018, 196-197 
bersyukur menjadi solusi untuk tidak menjadi pelaku social climber ini. Rasul Paulus mengemuakan untuk "Mengucap syukurlah dalam segala hal, sebab itulah yang dikehendaki Allah di dalam Kristus Yesus bagi kamu (1 Tes. 5:18). Mengucap syukur dalam bahasa Yunani menggunakan kata غ̇v $\pi \alpha v \tau i$

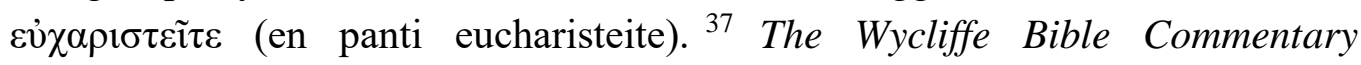
menafsirkan ayat ini agar dalam segala sesuatu termasuk ketika dalam penganiayaan atau masa-masa yang sulit, untuk tetap bersikap bersukacita senantiasa, tetap berdoa tanpa berkeputusan tanpa batas. ${ }^{38}$ Bila diaplikasikan ayat firman Tuhan ini dalam menjalani kehidupan, orang percaya diajar untuk menerima keadaan yang dialaminya baik dalam keadaan menderita terlebih dalam keadaan kekurangan sandang pandangan. Memupuk sikap mengucap syukur akan keadaan yang dialami dan apa yang dimiliki, tentunya mencegah umat Tuhan menjadi pelaku social climber.

Kemudian solusi yang kedua agar tidak menjadi pelaku dari social climber ini adalah dengan cara memilih pergaulan yang baik. Pergaulan dapat menyebabkan orang bisa menjadi pelaku dari sosial climber ini. Terkadang 'penyakit' social climber disebabkan oleh pengaruh pergaulan yang buruk seperti komunitas yang hobi Hang Out (atau sering ke mall). Oleh karena itu jika merasa tidak mampu mengimbangi gaya hidup mereka yang kelewat boros atau tidak sehat, sebaiknya memilih pergaulan yang baik atau meningkatkan potensi dibanding mengikuti arah gaya para social climber. ${ }^{39}$ Alkitab pun mengingatkan orang percaya bahwa pergaulan yang buruk akan berpotensi merusak kebiasaan yang baik (1 Kor 15:33). Bijak memilih pergaulan yang baik mencegah diri serta kita tidak menjadi terperangkap pada gaya hidup para pelaku social climber.

\section{Peran Gereja Kepada Para Pelaku Social Climber}

Apabila di lingkup gereja ada anggota jemaat sebagai pelaku dari social climber, maka gereja tidak boleh menjadi hakim bagi jemaat tersebut. Sebaliknya, di sinilah gereja harus menunjukkan perannya sebagai pendidik hidup jemaat untuk diarahkan agar kehidupan jemaat semakin mencerminkan sifat-sifat Kristus. Gereja harus menata cara hidup jemaat yang sesuai dengan

\footnotetext{
${ }^{37}$ Hasan Sutanto, Perjanjian Baru Interlinear Yunani-Indonesia \& Konkordansi Perjanjian Baru Jilid 1-2 (Malang: Gandum Mas, 2003), 1096.

${ }^{38}$ The Wycliffe Bible Commentary (Malang: Gandum Mas, 2008), 841.

39 "mengenal-fenomena-social-climber-perilaku-inngin-tampil-kaya-di-media-sosial", http://cicit.id/baca/
} 
firman Tuhan melalui pembelajaran dari Alkitab. Pembelajar yang gereja lakukan kepada jemaat dengan cara, mengkhotbahkan ayat-ayat firman Tuhan yang menghimbau bagaimana seharusnya menampilkan gaya hidup maupun gaya dalam berpakain. Seperti yang diungkapkan rasul Petrus, "Perhiasanmu janganlah secara lahiriah, yaitu dengan mengepang-ngepang rambut, memakai perhiasan emas atau dengan mengenakan pakain yang indah-indah, tetapi perhiasanmu ialah manusia batiniah yang tersembunyi dengan perhiasan yang tidak binasa yang berasal dari roh yang lemah lembut dan tentram, yang sangat berharga di hadapan Allah. Sebab demikianlah caranya perempuan-perempuan kudus dahulu berdandan, yaitu perempuan-perempuan yang menaruh pengharapannya kepada kepada Allah; mereka tunduk kepada suaminya." (1 Ptr. $3: 3-5)$.

Apabila gereja maupun pendeta sering mengajarkan bagaimana menampilkan dan menggunakan aksesoris dibadani sesuai dengan konsep Alkitab, maka jemaat akan terdidik serta dapat dicegah untuk tidak terjebak pada pola perilaku social climber. Dengan mendidik anggota jemaat tentunya mencegah tidak menampilkan gaya hidup yang bermewah-mewah sebagai fokus utama dalam menjalani kehidupan umat Tuhan.

\section{Keluarga pendeta menjadi teladan dalam menampilkan gaya hidup}

Pendeta dan kelurganya juga dituntut untuk menjadi teladan dalam menampilkan gaya hidup di hadapan jemaat. Riggs mengemuakan "seorang hamba Tuhan harus memiliki kehidupan yang benar, diterima oleh masyarakat gereja, ini adalah sebuah integritas diri yang sangat penting dalam menunjang diri sebagai hamba Tuhan. ${ }^{40}$ Jangan sampai hamba Tuhan atau keluarganya dihinggapi bibit-bibit social climber dari apa yang ditampilkan baik di media sosial maupun dalam dunia nyata. Misalnya dalam dunia maya, sering sekali para hamba Tuhan dan keluarganya entah disengaja atau tidak, kerap memposting hal-hal material seperti mobil, HP, meng-upload jenis makanan apa yang di makan di restoran. Mempublis yang sifatnya hal material dan diperlihatkan dalam ranah umum, berpotensi di cap sebagai orang yang pamer dan sarat pembanggaan diri. Sifat pembanggaan diri sangatlah melakat dalam diri setiap para pelaku Social Climber.

Dalam kehidupan nyata, pendeta dan keluarganya juga haruslah bersikap penuh bijaksana ketika menampilkan gaya hidup di hadapan jemaat. Jadilah

\footnotetext{
${ }^{40}$ Ralph M. Riggs, Gembala Sidang Yang Berhasil (Malang: Gandum Mas, 1996), 18.
} 
teladan contoh bagi jemaat dalam menampilkan cara hidup yang sederhana tanpa bersikap pamer sekalipun mampu secara ekonomi. Sebab, ekonomi jemaat amatlah beragam, ada yang kaya, sedang, maupun miskin. Dari keragaman ekonomi jemaat itu, maka pendeta dan keluarganya harus menjadi contoh dalam menampilkan bagaimana cara hidup yang sesuai dengan Alkitab.

Sudah sepatutnya keluarga hamba Tuhan menjadi satu praktek percontohan karakteristik dalam pelayanan, baik pengalaman-pengalaman yang ia alami itu dapat menjadi satu pelajaran untuk mengetahui langsung bagaimana kehidupan keluarga. Dan melalui kehidupan hamba Tuhan dengan keluarganya, ia dapat secara tidak langsung memberikan contoh kepada sekitarnya yaitu bagaimana sesungguhnya kehidupan keluarga hamba Tuhan yang baik dan harmonis dan yang berkenan kepada Allah. ${ }^{41}$ Jangan sampai pendeta mengajari hal yang benar, tetapi justru ia juga pelaku dari yang salah. Hendaklah mengingat apa yang diungkapkan rasul Paulus "Tetapi aku melatih tubuhku dan menguasainya, supaya sesudah memberitakan injil kepada orang lain, jangan aku sendiri ditolak." (1 Kor. 9:27).

\section{Kesimpulan}

Boleh saja berhasrat untuk menaikkan status hidup ke level yang lebih tinggi, karena pada dasarnya manusia mengharapkan adanya peningkatan secara ekonomi dan kemapanan hidup. Dengan bertambahnya peningkatan kemapanan ekonomi, maka secara otomatis ia akan mendapatkan kesetaraan pengakuan dari komunitas yang lebih elit. Apabila ada hasrat untuk menggapai hal ini di dalam diri seseorang tentunya itu tidaklah salah asalkan ia meraihnya dengan berusaha dan bertekun dengan bekerja keras dan proses yang benar. Yang salah itu apabila berambisi untuk mencari pengakuan kesetraan diri hanya dengan bermodalkan aksesoris yang berbalut kemewahan, tanpa ditopang dengan kematangan ekonomi karena tidak adanya prestasi dan karir yang dicapai. Pada umumnya orang-orang yang berlabel social climber hampir bisa dipastikan motif utama mereka, hanya berfokus bagaimana menghiasi dirinya dengan aksesoris barang-barang mahal dan tampilan dirinya dari luar yang serba mewah. Mereka tidak mempedulikan apakah ia mumpuni secara karir atau ekonomi, karena kepuasan utama bagi dirinya menerima pujian serta pengakuan dari orang-orang yang melihatnya. Selain itu, pelaku social climber dapat terjerumus

${ }^{41}$ Bernike Sihombing, "Kepribadian dan Kehidupan Hamba Tuhan Menurut 1 Timotius 3:1-13”, Kurios, Vol. 2, No. 1, Oktober, 2014, 10-11. 
melakukan praktik-praktik penipuan karena gaya hidup mewah menuntut dia tetapi keberadaan materi tidak menunjang untuk ia memiliki.

Apabila isu social climber ini dikaji dari persfektif iman Kristen amatlah berlawanan dengan nilai-nilai kebenaran firman Tuhan. Oleh karena prinsip firman Allah memberitahukan bagaimana orang percaya untuk bersikap dalam menjalani hidup untuk menampilkan sewajarnya saja dengan dengan nilai-nilai pondasi firman Tuhan. Yesus Kristus berkata bahwa Salomo saja yang kehidupannya penuh dengan limpahan meteri, tetapi IA berkata bahwa pakainnya tidak seindah bunga bakung (Mat. 6:29).

Social climber sangat rawan menyeret para pelakunya berfokus pada kesenangan duniawi sebagai yang utama. Social climber tidak mengajarkan berlomba dan bertekun untuk mencapai apa yang diharapkan dengan bekerja keras serta berusaha meningkatkan potensi diri, tetapi justru mendorong para pelakunya untuk sesibuk dan seupaya mungkin menghiasi drinya dengan aksesoris yang menempel ditubuhnya agar menerima sanjungan kesetaraan terhadap kaum para sosilita. Social climber juga membuat pelaku menjadi pribadi yang tidak siap menerima keadaan dirinya yang sebenarnya, sehingga menumpulkan budaya rasa malu atas hidupnya.

\section{Daftar Pustaka}

Brake, Andrew, Spiritual Formation, Bandung: Yayasan Kalam Hidup.

Bertens, K., Psikoanalisa Sigmund Freud, Jakarta: Gramedia Pustaka Utama, 2006.

Bhasin, Kamla, Menggugat Patriarki-Pengantar tentang Persoalan Dominasi terhadap Kaum Perempuan, Yogyakarta: Yayasan Bentang Budaya, 1996.

Darajat, Zakiah, Kesehatan Mental, Jakarta: Gunung Agung, 1983

Jong-Fast, Molly, The Social Climber's: Handbook, New York: Villard Books, 2011.

Mulyana, Dedy, Metode Penelitian, Bandung: Rosdakarya, 2002.

Rigs, Ralph M., Gembala Sidang Yang Berhasil, Malang: Gandum Mas, 1996.

Sutanto, Hasan, Perjanjian baru Interlinear Yunani-Indonesia \& Konkordansi Perjanjian Baru Jilid 1-2, Jakarta: Lembaga Alkitab Indonesia, 2002.

Scazzero, Peter, Emotionally Healtyy Spirituality, Surabaya: Literatur Perkantas Jawa Timur, 2017.

Santoso, Benny, Bebas dari Kekurangan Uang, Yogyakarta: ANDI, 2010.

Stott, John, Isu-Isu Global Menentang Kepemimpinan Kristiani, Jakarta: Yayasan Bina Kasih/OMF, 1996. 
Singgih, E. Gerrit, Vivat Crescat Floreat: Belajar \& Bertumbuh Bersama, Refleksi atas Setengah Abad Persetia, Jakarta: BPK Gunung Mulia, 2014.

Soedarsono, Soemarno, Penyemaian Jati Diri, Jakarta: Elek Media Komputindo, 2000.

Yusuf, L. dan Syamsu N., Kesehatan Mental-Perspektif Psikologis \& Agama, Bandung: PT Remaja Rosdakarya, 2018.

\section{Alkitab \& Buku Tafsir}

Alkitab, Jakarta: Lembaga Alkitab Indonesia, 2012.

Tafsiran Alkitab Masa Kini 3 Matius-Wahyu, Jakarta: Yayasan Komunikasi Bina Kasih/OMF, 2001.

The Wycliffe Bible Commentary, Malang: Gandum Mas, 2008.

Tafsiran Alkitab MHC, versi eloktronik.

\section{Jurnal}

Bernike Sihombing, "Kepribadian dan Kehidupan Hamba Tuhan Menurut 1 Timotius 3:1-13", Kurios, Vol. 2, No. 1, 2014.

Nurudin \& Muyassarah, "Menilik Perempuan Sebagai Social Climber Dalam Pandangan Ekonomi Islam", SAWWA, Vol. 12, Nomor 2, 2017.

Nugroho, Widhi Arief, "Peranan Pendidikan Keluarga Tentang kekudusan Hidup Menurut Roma 12:1-2, Fidei: Jurnal Teologi Sistematika dan Praktika, Vol. 1, No. 2, 2018.

\section{Internet}

https://batam.tribunnews.com, "waspada-bahaya-social-climber.

http://supraptiprapti.gurusiana.id/article/social-climber-, "saran-psikolog-saathadapi-perilaku-social-climber-di-medsos"

https://health.detik.com/berita-detikhealth/, 'suka-pamer-seperti-social-climberini-dampaknya-bagi-kesehatan jiwa"

https://www.inovasee.com/, "mengenal-socal-climber-orang-miskin-yang-inginkelihatan-kaya"

https://www.cnnindonesia.com, "rentetan-kasus-korupsi-yang-menjerat-

pegawai-pajak" https://hanyalewat.com, "Social-climber-penyakit-jiwa-meruntuhkan-bangsa" https://womantalk.com/friendship/articles/, "awas-5-tanda-tanda-social-climberyang-paling-mencolok" http://cicit.id/baca/, "mengenal-fenomena-social-climber-perilaku-ingin-tampilkaya-di-media-sosial" 